\title{
Clinicopathological study of pancreatic and ganglioneuroblastoma tumours secreting vasoactive intestinal polypeptide (vipomas)
}

\author{
R G LONG， M G BRYANT，S J MITCHELL，T E ADRIAN, J M POLAK， S R BLOOM
}

\begin{abstract}
During a six-year period (1973-9) 52 patients with pancreatic tumours and 10 with ganglioneuroblastomas were found to have raised plasma vasoactive intestinal polypeptide (VIP) concentrations. All the patients had severe secretory diarrhoea, weight loss, dehydration, hypokalaemic acidosis, and a raised plasma urea concentration. Reduced gastric acid secretion was seen in $72 \%$ of patients. Plasma VIP concentrations were not raised in patients with diarrhoea due to other types of tumour or disease or in hormone-secreting tumours not associated with diarrhoea. Plasma VIP measurement may therefore give clinical guidance in a patient with persistent watery diarrhoea and hypokalaemic acidosis. Surgical excision was clearly the treatment of choice, but metastatic pancreatic tumours usually responded to streptozotocin.
\end{abstract}

\section{Introduction}

In 1958 Verner and Morrison ${ }^{1}$ described two cases of severe watery diarrhoea associated with non-insulin secreting islet cell adenomas of the pancreas. This association has variously become known as the Verner-Morrison syndrome, the WDHA syndrome (watery diarrhoea, hypokalaemia, and achlorhydria), or pancreatic cholera. Other features described include spontaneous cutaneous flushing, hypokalaemic renal failure, reduced or absent gastric acid secretion, diabetes mellitus, and hypercalcaemia. ${ }^{23}$ An association between ganglioneuroblastomas and diarrhoea, usually in children, has also been described. ${ }^{4}$ Failure to recognise these conditions may result in the untoward death of patients with treatable tumours.

Vasoactive intestinal polypeptide (VIP) is a basic 28 aminoacid peptide present in the central and peripheral nervous system. High concentrations of VIP are found in the gastrointestinal tract, and its role as a putative neurotransmitter has recently been supported by neurophysiological experiments. ${ }^{5}$ Infusion studies have shown several biological actions including stimulation of intestinal secretion, vasodilatation, inhibition of gastric acid secretion, stimulation of glycogenolysis, and the production of hypercalcaemia. ${ }^{6}$ In 1973 raised plasma and tumour concentrations of VIP were found in patients with the VernerMorrison syndrome and in a patient with a ganglioneuroblastoma and secretory diarrhoea. ${ }^{7}$ We report our experience of vipomas (VIP secreting pancreatic and neural crest tumours) from 1973 to 1979 .

\section{Patients and methods}

Since 1974 a service has been provided at Hammersmith Hospital to screen plasma specimens referred from other hospitals for raised plasma VIP concentrations. Most plasmas screened have been from 
patients with diarrhoea. We report on the first 62 patients seen with raised plasma VIP concentrations, but full preoperative clinical details were available on only 43 patients ( 33 had pancreatic tumours and 10 ganglioneuroblastomas). The incidence of plasma VIP concentrations over $30 \mathrm{pmol} / \mathrm{l}$ in patients with other proved causes of diarrhoea-for example, purgative abuse and inflammatory bowel disease-with other functioning tumours-for example, medullary carcinoma of the thyroid and carcinoid tumours-and with pancreatic and gastrointestinal adenocarcinomas is also included.

It was requested that fasting blood for VIP estimation should be collected into heparinised tubes containing 400 Kallikrein-inactivating units of aprotinin (Trasylol)/ml blood, be immediately centrifuged, and the plasma separated and stored at $-20^{\circ} \mathrm{C}$. VIP in plasma and tissue extracts was measured by a specific radioimmunoassay capable of detecting 1.5 pmol VIP $/ 1$ plasma with $95 \%$ confidence. ${ }^{8}$ The tumour content of VIP was measured in tissue kept at $-20^{\circ} \mathrm{C}$; the tissue was boiled briefly to inactivate proteolytic enzymes and was extracted by homogenisation first in water and then in $0.1 \mathrm{M}$ formic acid. Plasma and tissue pancreatic polypeptide was also measured by radioimmunoassay. ${ }^{9}$ The tumour tissue was examined by both standard histological techniques and immunocytochemical techniques, including the simultaneous localisation of multiple tissue antigens, ${ }^{10}$ the use of single sections for the consecutive double immunostaining of tissue antigens, ${ }^{11}$ the use of semithin-thin sectioning, ${ }^{12}$ and the peroxidase, antiperoxidase method at the ultrastructural level. ${ }^{13}$

\section{Results}

A primary tumour of the pancreas was found in 52 of the patients and a neural crest tumour in 10 . All the 52 patients with pancreatic tumours were adults (mean age 49 ; range $32-75$ ), and there was a slight preponderance of women ( $M: F \quad 24: 28)$. The sex ratio of the patients with ganglioneuroblastomas was equal: seven of the 10 with ganglioneuroblastomas were children (mean age 4 years 1 month, range 10 months to 9 years) and there were three adults, aged 32, 61, and 62 .

\section{SYMPTOMS}

All patients had had a prolonged period of continuous or intermittent profuse watery diarrhoea of more than $20 \mathrm{ml} / \mathrm{kg} /$ day (1 litre a day in adults). The diarrhoea was cyclical in some patients who had pronounced relapses and remissions. The duration of diarrhoea before diagnosis had varied from two months to four years. Gross steatorrhoea was absent, and in no patient did the daily faecal fat concentrations exceed $54 \mathrm{mmol}(15 \mathrm{~g})$. All the patients had pronounced weight loss; in adults this was 7-27 $\mathrm{kg}$ since the onset of diarrhoea, and this could not be explained by dehydration alone. Abdominal colic was common $\left(63^{\circ}\right)$ and occasionally precipitated admission to hospital. Spontaneous facial (and sometimes whole body) flushing was noted in nine patients $(21 \%)$. Two patients had renal calculi, which was associated with hypercalcaemia, and both had unilateral hydronephrosis requiring surgery. Despite VIP being a neural peptide there was no evidence that the patients' mental state was inappropriate to the illness.

One of the patients (a man aged 38) with a pancreatic tumour had multiple endocrine adenomatosis type I with gynaecomastia, galactorrhoea, an enlarged sella turcica, and hyperparathyroidism. Two patients with pancreatic tumours had a family history of pancreatic endocrine tumours - the man above with multiple endocrine adenomatosis type I had a sister with multiple insulinomas and a brother with a gastrinoma and another 38-year-old man had a brother with an insulinoma and a parathyroid adenoma.

\section{BIOCHEMICAL RESULTS (table I)}

The mean $( \pm$ SEM) plasma VIP in 41 normal fasting controls was $3.4 \pm 0.4 \mathrm{pmol} / 1$ (range $0.5-16 \mathrm{pmol} / \mathrm{l}$ ) and in the first received sample of the 62 vipomas was $203 \pm 17 \mathrm{pmol} / \mathrm{l}$ with a range of $48-760 \mathrm{pmol} / \mathrm{l}$ (fig 1). At presentation the mean plasma VIP concentrations in the patients with pancreatic vipoma was $211 \pm 19 \mathrm{pmol} / 1$ and in those with ganglioneuroblastomas $162 \pm 30 \mathrm{pmol} / \mathrm{l}$.

All patients had hypokalaemia, which was often severe, and the serum potassium concentration was under $2.5 \mathrm{mmol} / 1$ at some stage in 40 of $43(93 \%)$ patients. It was associated with an inappropriately low plasma bicarbonate concentration, under $15 \mathrm{mmol} / 1$ at some stage $\underline{\underline{T}}$ in 36 of $43(84 \%)$ patients. A raised plasma urea concentration was always present at some stage but usually appeared to be related to $\mathbb{D}$ dehydration as it could be restored to normal by intravenous fluids. $\stackrel{c}{c}$

TABLE I-Incidence of abnormal biochemical results in vipomas $(\%)$

\begin{tabular}{|c|c|}
\hline $\left.\begin{array}{l}\text { Raised plasma VIP concentration } \\
\text { Hypokalaemic acidosis } \\
\text { Raised plasma urea concentration }\end{array}\right\}$ & $\begin{array}{r}100 \\
72 \\
65 \\
50 \\
42\end{array}$ \\
\hline
\end{tabular}

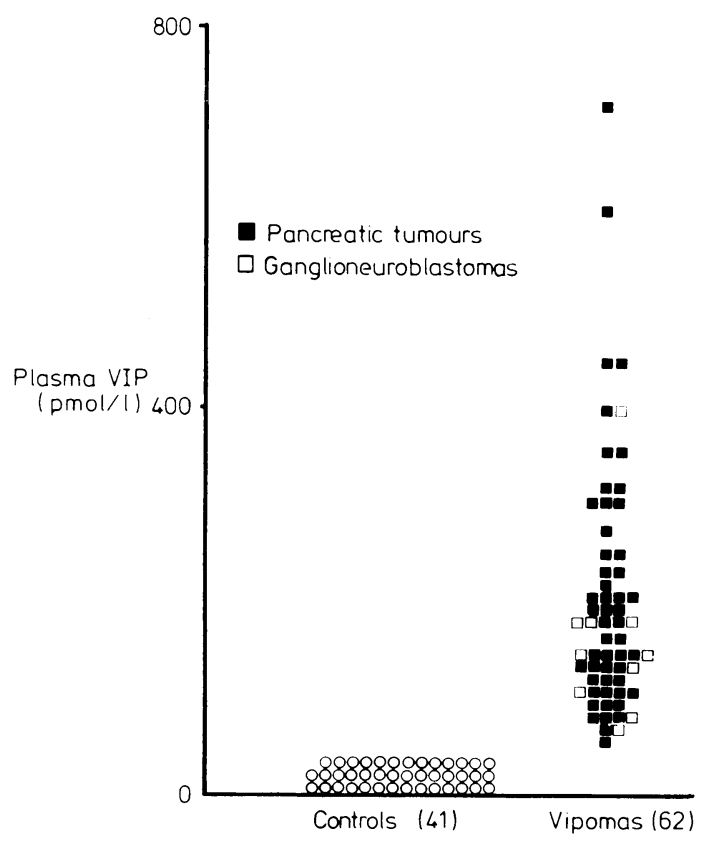

FIG 1-Plasma VIP concentration (pmol/1) in 41 normal subjects and 62 vipoma patients.

A raised fasting plasma pancreatic polypeptide concentration (above $300 \mathrm{pmol} / \mathrm{l})$ was seen in 40 of the $52(77 \%)$ patients with pancreatic vipomas (normal concentration under $100 \mathrm{pmol} / \mathrm{l}$ ). Conversely, plasma :concentrations of pancreatic polypeptide in all 10 with ganglio- 3 neuroblastomas were normal (mean $\perp S E M 40 \pm 8$ pmol/1). Hyperinsulinaemia associated with hypoglycaemia was observed in one 의 patient with a pancreatic tumour.

Achlorhydria or hypochlorhydria were both common, but $28 \%$ of 윽 the patients assessed had gastric acid secretion within the normal N range. Both hypophosphataemia and hypercalcaemia were common, five patients having a much raised fasting serum calcium concentration of over $3.0 \mathrm{mmol} / 1$ (normal under $2.65 \mathrm{mmol} / \mathrm{l}$ ) at some period. In the hypercalcaemic patients both serum 25 -hydroxy vitamin $D$ and $N$ parathyroid hormone concentrations were normal when measured. $N$ The hyperglycaemia was mild (fasting blood glucose under $10 \mathrm{mmol} / \mathrm{l}$ ) and did not require treatment.

\section{NATURE OF THE TUMOUR}

Fifty-two of the tumours were classic endocrine tumours of the pancreas with a characteristic arrangement of tumour cells. There was $\frac{O}{\mathbb{D}}$ a wide range in size but most were under $8 \mathrm{~cm}$ in diameter. In only one of these tumours was there evidence of more than one pancreatic tumour (three), but in $40 \%$ of patients there was evidence of $?$ metastases in either lymph nodes or the liver. Ten of the tumours were histologically extrapancreatic ganglioneuroblastomas, and in only one of these patients were metastases present.

Cells from the tumours were reactive to both VIP and pancreatic 
polypeptide antibodies, and these two peptides were shown to come from separate types of cell. Ultrastructural studies showed numerous electron-dense secretory granules having a mean $(+S D)$ diameter of $189.54+42.55 \mathrm{~nm}$ and others of a mean diameter of $169 \cdot 26+42.57$ $\mathrm{nm}$; both were round, electron-dense, and with a characteristic core and halo. In view of the close morphological similarities of the two types of granules, full characterisation of VIP or pancreatic polypeptide, or both, was carried out, ${ }^{12}{ }^{13}$ and the smaller granules (mean $169.26 \mathrm{~nm}$ ) were those containing VIP, whereas pancreatic polypeptide secretory granules tended to be somewhat larger. Radioimmunoassay of VIP content has been performed on 40 vipoma tumours (fig 2). The mean ( + SEM) VIP in the 40 tumours was $619 \pm 95 \mathrm{pmol} / \mathrm{g}$ wet tissue compared with $33 \pm 8 \mathrm{pmol} / \mathrm{g}$ in normal pancreatic tissue from seven controls. Pancreatic polypeptide in normal pancreas was $907 \pm 284 \mathrm{pmol} / \mathrm{g}$ wet tissue and in pancreatic tumours was $1248+370 \mathrm{pmol} / \mathrm{l}$ wet tissue. Pancreatic polypeptide was not detectable in extracts of ganglioneuroblastoma tissue.

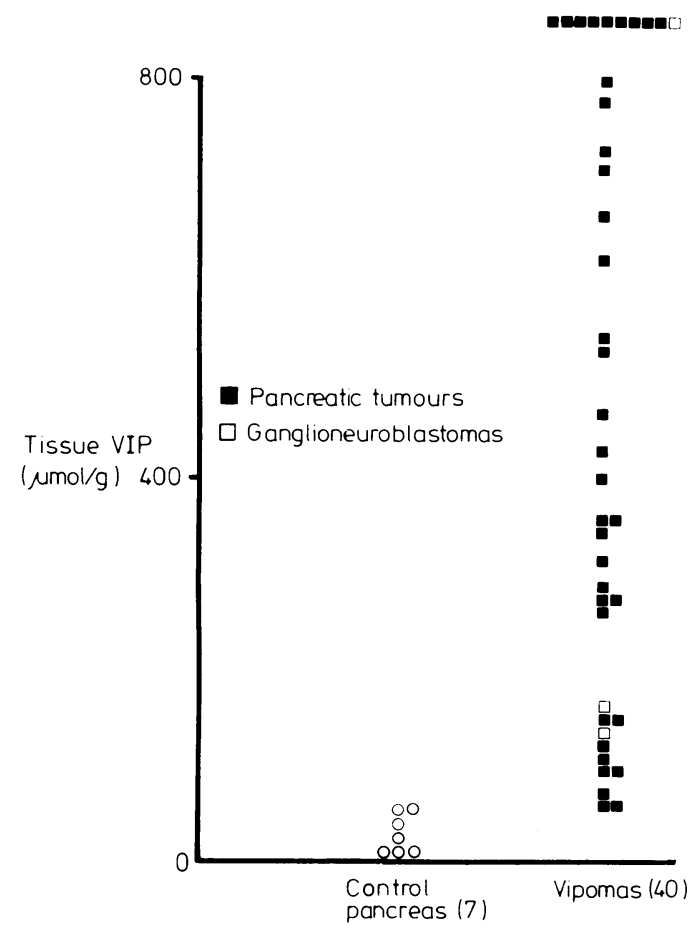

FIG 2-Tissue VIP concentrations ( $\mathrm{pmol} / \mathrm{g}$ wet tissue) in seven normal pancreas specimens and 40 vipoma tumours.

\section{PLASMA VIP IN OTHER DISEASES}

A screen of patients with diarrhoea (more than five motions a day or over $500 \mathrm{~g}$ faeces a day, or both) and other patients with endocrine tumours and lesser or no diarrhoea showed no patient with plasma VIP concentrations of over $30 \mathrm{pmol} / \mathrm{l}$ (table II).

TABLE II-Incidence of raised plasma VIP concentration in other causes of diarrhoea and other tumours

\begin{tabular}{|c|c|c|c|}
\hline \multicolumn{4}{|c|}{ Tumours with diarrhoea } \\
\hline $\begin{array}{l}\text { Medullary carcinoma of thyroid } \\
\text { Carcinoma of bronchus }\end{array}$ & $\begin{array}{l}0 / 11 \\
0 / 12\end{array}$ & $\begin{array}{l}\text { Carcinoid syndrome } \\
\text { Gastrinoma }\end{array}$ & $\begin{array}{l}0 / 32 \\
0 / 26\end{array}$ \\
\hline \multicolumn{4}{|c|}{ Non-tumour causes of diarrhoea } \\
\hline $\begin{array}{l}\text { Purgative abuse } \\
\text { Crohn's disease } \\
\text { Ulcerative colitis } \\
\text { Acute infection }\end{array}$ & $\begin{array}{l}0 / 11 \\
0 / 23 \\
0 / 19 \\
0 / 23\end{array}$ & $\begin{array}{l}\text { Pancreatic insufficiency } \\
\text { Short-gut syndrome } \\
\text { Diabetic diarrhoea }\end{array}$ & $\begin{array}{l}0 / 36 \\
0 / 11 \\
0 / 14\end{array}$ \\
\hline \multicolumn{4}{|c|}{ Other tumours without diarrhoea } \\
\hline $\begin{array}{l}\text { Insulinomas } \\
\text { Ectopic adrenocorticotrophic } \\
\text { hormone secreting tumours } \\
\text { Non-pancreatic gut } \\
\text { adenocarcinomas }\end{array}$ & $\begin{array}{l}0 / 17 \\
0 / 23 \\
0 / 28\end{array}$ & $\begin{array}{l}\text { Glucagonomas } \\
\text { Pituitary tumours } \\
\text { Adenocarcinoma of the pancreas }\end{array}$ & $\begin{array}{l}0 / 17 \\
0 / 40 \\
0 / 17\end{array}$ \\
\hline
\end{tabular}

RESPONSE TO TREATMENT (table III)

Surgical excision of the primary pancreatic tumour relieved all the symptoms in 17 patients. No metastases were seen at operation in 15 patients, but two patients had several small unresected metastases that were still asymptomatic one and a half and two years postoperatively. Streptozotocin gave a remission of symptoms and a fall in plasma VIP concentration in seven patients for one to three years and five of these seven patients remain in remission while taking this drug.

TABLE III-Response of vipomas to treatment

\begin{tabular}{lcc}
\hline & Effective & Ineffective \\
\hline \multicolumn{3}{c}{ Pancreatic adenomas } \\
Surgery & 17 & 7 \\
Streptozotocin & 7 & 1 \\
Corticosteroids & 5 & 1 \\
Fluorouracil/carmustine & 1 & 0 \\
\multicolumn{4}{c}{ Ganglioneuroblastomas } \\
Surgery & 7 & 2
\end{tabular}

Corticosteroids gave a symptomatic remission in five patients, the patient failing being the one who had failed to respond to streptozotocin. Fluouracil followed by carmustine gave a remission for four years in one patient.

Surgical removal of the ganglioneuroblastomas was successful in seven of the patients, but total excision was impossible in two and they died postoperatively. The 10 -month-old baby died preoperatively from hypokalaemia and renal failure.

\section{Discussion}

Although it was once reported that raised plasma VIP concentrations might occur in patients with bronchial carcinomas and pancreatic islet cell hyperplasia, ${ }^{14}$ in our experience and that of others ${ }^{4}$ VIP-secreting tumours appear to originate usually in the pancreas ${ }^{15}$ and sympathetic chain. ${ }^{16}$ The plasma VIP concentration is raised immediately after extensive tissue ischaemia, ${ }^{17}$ but otherwise a raised plasma VIP concentration suggests a vipoma. It remains controversial whether the VernerMorrison syndrome can be mediated by substances other than VIP-for example, prostaglandins. ${ }^{18}$ No other mediators are proved, and most patients (all in our experience) with nongastrin secreting pancreatic endocrine tumours or ganglioneuroblastomas associated with severe watery diarrhoea have raised plasma VIP concentrations if sample collection, storage, and radioimmunoassay are correctly performed.

The acronym vipoma seems the most appropriate term for VIP secreting pancreatic and neural crest tumours, and these neoplasms result in a well-defined clinical syndrome. The plasma VIP concentrations in the original cases are unknown, and possibly Verner and Morrison's original cases were, in fact, gastrinomas. The WDHA (watery diarrhoea, hypokalaemia, and achlorhydria) syndrome seems an inappropriate and misleading term as in the present series $28 \%$ of the patients studied had normal gastric acid secretion. Pancreatic cholera implies infection and also could be discarded as an inadequate description.

The biological actions of VIP accord well with the changes seen in patients with vipomas. In man exogenous VIP infusion produces not only a striking inhibition of jejunal and colonic water and electrolyte absorption but is even associated with net secretion into the intestine" 1920 ; hence the term "secretory diarrhoea." In VIP infusion studies in pigs there is a pronounced secretory diarrhoea ${ }^{21}$ when plasma VIP concentrations similar to those seen in vipomas are produced. VIP shares amino-acid sequence homologies, and also several biological actions with the hormone pancreatic glucagon. This homology may explain the tendency to loss of weight and hyperglycaemia that occurs in patients with vipomas. Some of the VIP in the plasma of patients with vipomas appears to be of greater molecular size 
than 28 amino-acid VIP, and there is preliminary evidence that this is biologically less active than the 28 amino-acid molecule. ${ }^{22}{ }^{23}$ Despite the presence of VIP in nerves no inappropriate neuropsychiatric symptoms have occurred during infusion of VIP or been noted in patients with tumours, perhaps because VIP does not cross the blood brain barrier. Thus the pathological changes noted in patients with vipoma may reasonably be explained by the biological actions of VIP alone.

Vipomas present in three main ways: firstly, as persistent or intermittent secretory diarrhoea in patients in whom other routine investigations give negative results; secondly, with very acute severe diarrhoea, hypokalaemic acidosis, and prostration in patients who need urgent admission to hospital; and, thirdly, as a tumour in patients who are then noted to have or to develop diarrhoea. All three groups are biochemically characterised by hypokalaemia and usually also by a low plasma bicarbonate concentration; the combination of pronounced diarrhoea and hypokalaemic acidosis is an indication to measure the plasma VIP concentration. Interestingly we have diagnosed six patients in the first group who were having long-term follow-up in outpatients and were admitted for the first time as a result of finding a high plasma VIP concentration on routine screen and who were then found to have a VIP-secreting tumour. Four of these patients subsequently underwent successful operation with apparent total excision of the tumour and loss of symptoms.

It is common for pancreatic vipomas to secrete also pancreatic polypeptide. One patient with a pancreatic tumour secreted insulin (with hypoglycaemia) and VIP, and another with a ganglioneuroblastoma secreted noradrenaline and VIP. These substances may also be identified in operative tumour specimens by histochemical and biochemical techniques. ${ }^{23}$ It thus seems that some of these tumours contain separate cells that synthesise other active substances, but in the patients described here VIP appeared to dominate and be the major cause of symptoms.

Multiple endocrine adenomatosis type I consists of the triad of functioning endocrine pancreatic, parathyroid, and pituitary tumours with dominant inheritance. ${ }^{24}$ In this series a family history of pancreatic endocrine tumours occurred in two patients, and there was one case of multiple endocrine adenomatosis type I. A recent report documented a patient whose father had a gastrinoma and who himself had had a vipoma resected and then a parathyroid adenoma removed three years later. ${ }^{25}$ Hence apparently vipomas do occur as part of multiple endocrine adenomatosis type I and parathyroid and pituitary function should be checked in all patients with a pancreatic vipoma.

The preoperative localisation of vipomas is often difficult because of their small size. Selective pancreatic, hepatic, and sympathetic chain arteriography has been the most rewarding investigation at Hammersmith Hospital, and all primary tumours have been successfully located at first admission. ${ }^{26}$ Portal venous sampling and measurement of the VIP concentration to indicate the site of venous outflow of pancreatic tumours may have a role in doubtful cases ${ }^{27}$ but is not without risk, for example, of biliary peritonitis. Follow-up for detection of recurrence or during treatment of malignant tumours is greatly helped by monitoring plasma VIP concentrations as they become detectably raised usually long before symptoms develop.

If the condition is diagnosed early the opportunity for successful excision and possible complete cure is likely to be greater. Delay may result in greater tumour size and local invasion. Patients with undiagnosed benign tumours may even die acutely owing to hypokalaemia, dehydration, and renal failure. ${ }^{1}$ Short-term symptomatic remissions are common with very high-dose corticosteroid treatment, but relapse is invariable, usually in under two months. Indomethacin ${ }^{18}$ metoclopramide, ${ }^{23}$ lithium, ${ }^{28}$ and trifluoperazine ${ }^{29}$ have been reported as effective in suppressing diarrhoea in single cases, but it would appear that these are idiosyncratic responses. Streptozotocin, in contrast, seems to be highly effective and, in conjunction with careful monitoring of renal function, should be used in patients with inoperable metastases. ${ }^{30}{ }^{31}$ Recently its use in combination with fluorouracil has also been recommended. ${ }^{32}$
We conclude that VIP-producing tumours result in a defined diarrhoeal condition best termed the vipoma syndrome. Patients are readily diagnosed by the results of measurement of the plasma VIP concentration. Greater clinical awareness of this syndrome may lead to earlier detection and improve the chances of successful resection and symptomatic cure. The long-term recurrence rate is unknown, however, and warrants further study.

We are very grateful to the physicians and surgeons in Britain and abroad who have sent us plasma, tumour tissue, and clinical details of their patients with vipomas: this study would have been impossible without their co-operation. We are grateful for financial assistance from the Wellcome Trust, Medical Research Council, and Cancer Research Campaign.

\section{References}

${ }^{1}$ Verner JV, Morrison AB. Islet cell tumour and a syndrome of refractory watery diarrhoea and hypokalaemia. $\mathrm{Am} \mathrm{f}$ Med 1958;25:374-80.

${ }^{2}$ Kraft AR, Tompkins RK, Zollinger R. Recognition and management of the diarrhoea syndrome caused by nonbeta islet cell tumours of the pancreas. Am $\mathcal{F}$ Surg 1970;119:163-70.

${ }^{3}$ Verner JV, Morrison AB. Endocrine pancreatic islet disease with diarrhoea. Report of a case due to diffuse hyperplasia of nonbeta islet tissue with a review of 54 additional cases. Arch Intern Med 1974;133: 492-500.

4 Green M, Cooke RE, Lattanzi W. Occurrence of chronic diarrhoea in three patients with ganglioneuromas. Pediatrics $1959 ; 23: 951-5$.

${ }^{5}$ Fahrenkrug J, Haglund U, Jodal M, Lundgren O, Olbe L, Schaffalitsky de Muckadell OB. Nervous release of vasoactive intestinal polypeptide in the gastrointestinal tract of cats: possible physiological implications. f Physiol 1978;284:291-305.

${ }^{6}$ Said SI, Mutt V. Polypeptide with broad biological activity: isolation from small intestine. Science 1970;169:1217-8.

${ }^{7}$ Bloom SR, Polak JM, Pearse AGE. Vasoactive intestinal peptide and watery diarrhoea syndrome. Lancet 1973;ii:14-6.

${ }^{8}$ Mitchell SJ, Bloom SR. Measurement of fasting and postprandial VIP in man. Gut 1978;19:1043-8.

${ }^{9}$ Bjornsson OG, Adrian TE, Dawson J, et al. Effects of gastrointestinal hormones on fasting gall bladder storage patterns in man. Eur $\mathcal{F}$ Clin Invest $1979 ; 9: 293-300$.

10 Nakane PK. Simultaneous localisation of multiple tissue antigens using the peroxidase-labelled antibody method: a study on pituitary gland of the rat. $\mathcal{F}$ Histochem Cytochem 1968;16:557-60.

11 Tramu G, Pillez A, Leonardelli J. An efficient method of antibody elution for the successive or simultaneous localization of two antigens by immunocytochemistry. $\mathcal{F}$ Histochem Cytochem 1978;26:322-4.

12 Polak JM, Pearse AGE, Heath CM. Complete identification of endocrine cells in the gastrointestinal tract: use of the semithin-thin technique to identify motilin cells in human and animal intestine. Gut 1975;16:225-9.

13 Sternberger LA. The unlabelled antibody enzyme method. In: Immunocytochemistry. New Jersey: Prentice-Hall Inc, 1974:129-71.

14 Said SI, Faloona GR. Elevated plasma and tissue levels of vasoactive intestinal polypeptide in the watery-diarrhoea syndrome due to pancreatic, bronchogenic and other tumours. $N$ Engl f Med 1975;293: 155-60.

15 Cooperman AM, Desantis D, Winkelman E, Farmer R, Eversman J, Said S. Watery diarrhoea syndrome: two unusual cases and further evidence that VIP is a humoral mediator. Ann Surg 1978;187:325-8.

16 Mendelsohn G, Eggleston JC, Olson JL, Said SI, Baylin SB. Vasoactive intestinal polypeptides and its relationship to ganglion cell differentiation in neuroblastic tumours. Lab Invest 1979;41:144-9.

${ }^{17}$ Modlin IM, Bloom SR, Mitchell SJ. Plasma vasoactive intestinal polypeptide (VIP) levels and intestinal ischaemia. Experientia 1978;34: 535-6.

18 Jaffe BM, Kopen DF, De Schryver-Kecskemeti K, Gingerich RL, Greider M. Indomethacin-responsive pancreatic cholera. $N$ Englf Med $1977 ; 297: 817-21$

19 Krejs GJ, Fordtran JS, Bloom SR, et al. Effect of VIP infusion on water and ion transport in the human jejunum. Gastroenterology 1980;78: 722-7.

${ }^{20} \mathrm{Krejs}$ GJ. Effect of VIP infusion on water and ion transport in the human large intestine. Gastroenterology 1980;78:1200.

21 Modlin IM, Bloom SR, Mitchell SJ. Experimental evidence for vasoactive intestinal peptide as the cause of the watery diarrhoea syndrome. Gastroenterology $1978 ; 75: 1051-4$.

22 Yamaguchi K, Abe K, Miyakawa S, Ohnami S, Sakagami M, Yanaihara N. The presence of macromolecular vasoactive intestinal polypeptide (VIP) in VIP-producing tumours. Gastroenterology 1980;79:687-94.

${ }^{23}$ Long RG, Bryant MG, Yuille PM, Polak JM, Bloom SR. Mixed pancreatic apudoma with symptoms of excess vasoactive intestinal polypeptide and insulin: improvement of diarrhoea with metoclopramide. Gut (in press).

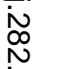 .


24 Majewski JT, Wilson SD. The MEA-1 syndrome: an all or none phenomenon? Surgery $1979 ; 86: 475-84$

${ }^{25}$ Hutcheon DF, Bayliss TM, Cameron JL, Baylin SM. Hormone-mediated watery diarrhoea in a family with multiple endocrine neoplasms. $A n n$ Intern Med 1979;90:932-4.

${ }^{26}$ Allison DJ. Therapeutic embolisation. Br f Hosp Med 1978;20:705-15.

27 Kingham JGC, Dick R, Bloom SR, Frankel RJ. Vipoma: localisation by percutaneous transhepatic portal venous sampling. $\mathrm{Br}$ Med $\mathcal{F}$ 1978;ii: 1682-3.

28 Pandol SJ, Korman LY, McCarthy DM, Gardner JD. Beneficial effect of oral lithium carbonate in the treatment of pancreatic cholera syndrome. N Engl f Med 1980;302:1403-4.
${ }^{29}$ Donowitz M, Elta G, Bloom SR, Nathanson L. Trifluoperazine reversal of secretory diarrhoea in pancreatic cholera. Ann Intern Med 1980;93: $283-5$.

${ }^{30}$ Kahn CR, Levy AG, Gardner JD, Miller JV, Gordon P, Schein PS. \ Pancreatic cholera: beneficial effects of treatment with streptozotocin. $\mathbb{Q}$ $N$ Engl f Med 1975;292:941-5.

31 Oberg K, Bostrom $\mathrm{H}$, Fahrenkrug J, Dymling JF, Schaffalitsky de Muckadell OB, Lundquist G. Streptozotocin treatment of a pancreatic tumour producing VIP and gastrin associated with Verner-Morrison syndrome. Acta Med Scand 1979;206:223-7.

${ }^{32}$ Moertel CG, Hanley JA, Johnson LA. Streptozotocin alone compared \& with streptozotocin plus fluorouracil in the treatment of advanced $\Pi$ islet-cell carcinoma. N Engl f Med 1980;303:1189-4.

\title{
Personal Paper
}

\section{Academic surgery: future uncertain}

\author{
H A F DUDLEY
}

Surgeons are practical men: they do things with their hands which every now and again make patients better. As with all craftsmen they have an innate suspicion of the theoretical. Even further, they may discount ideas newly minted and manifestly heterodox by comparison with the coinage of their experience (particularly the experience that they, or their immediate predecessors or contemporaries have gained, for on the whole beyond this they are anti-historical). Surgeons are the farmers of clinical medicine-bucolic of mien, relatively free from the agonies of self-examination, content to plough and harvest. Like farmers they complain-about the theatre, the instruments, and everything else. And like farmers they usually prosper. As with other tradesmen, they may take an apparently joking or casual attitude to their work - an approach which half conceals a proud technical mastery.

\section{Attitudinal differences}

The academic life is based on generalisation and concept. It is not necessarily theoretical, and I deplore any attempt to equate the words academic and theoretical. This usage is a modern corruption of an old and proud term derived from Platonic philosophy. Academic practice, however, tends to be seen as putting generalisations into effect, as much as dealing with a unique here and now. Academics-a word not used much in Britain and which again is a modern substitute for the rather more pleasant academians-are interested as much in things as in people. I do not mean material things but ideas and their transmission. They need time to be contemplative. As everyone who sits on university or medical school committees knows, the academic mind has a demoniacally destructive ability to see five facets of a four-sided problem simultaneously. Academics are thus often labelled indecisive. As the poet and scholar D J Enright ${ }^{1}$ put it: "academics customarily possess such a gift for subtle reasoning and fine distinctions, such exquisite professional scrupulosity and verbal dexterity, that even an intelligent and shrewd observer may fail to perceive that much of the time their basic motive is simple cynicism and self-interest."

Academic Surgical Unit, St Mary's Hospital, London W2 1NY

H A F DUDLEY, CHM, FRCS, professor of surgery and director of unit
He went on to say: "If you are in trouble, throw yourself on the mercy of the nearest peasant, publican or policeman, but 0 never go to an academic; you will be dead long before he has finished formulating his attitude towards you and your $\mathscr{O}^{\omega}$ problem."

To these characteristics we must add that at least until recently it was part of the academians' stock-in-trade not to $\vec{\varphi}$ prosper except by devious means such as writing novels under $\stackrel{\infty}{\rightarrow}$ pen names or appearing heavily disguised on television. Nevertheless, in their discipline they are usually deadly serious. Moreover, in both the act of research and its results they must often find themselves taking a heterodox stance. Finally, research requires introspection, intellectual agony, midnight oil, and flashes of insight of uncertain origin-qualities not easy to mix with long hours at the service of patients.

The two contrasting descriptions I have drawn lead inevitably to the conclusion that the words "academic" and "surgery" are totally incompatible, both attitudinally and in practice. While I do not believe this to be absolutely true, like all good fabrications this fallacy contains an element of the truth sufficient to require us to examine it with some concern.

Academic surgery - as represented by academic departments in the clinical field-has come into being at different times in $\delta$ history for three reasons: to provide a voice for clinical medicine 3 in the councils of the universities; to act as a focal point for 을 teaching and training; and to prosecute research. It would be a $\vec{N}$ useful if rather broad series of generalisations to say that the $O$ chairs in Scottish schools developed during the first half of the nineteenth century were for the first with a dash of the second; that the growth of academic clinical medicine in the last years of $N$ the nineteenth century and the first quarter of the twentieth $\mathbb{\omega}_{\mathbf{N}}$ in the USA was, in the wake of the Flexner report, mainly to do 0 with the second, supplemented at first by a drop of the third, 0 though latterly of course by a flood; and that the ultimate $\bar{D}$ recognition of the need for academic surgery in England in the $\stackrel{\mathscr{?}}{+}$ 'thirties - the story of which I have outlined elsewhere ${ }^{2}$-was 7 mainly to do with the third. On a slightly sour note I might well add that at least in part the objective in England has been to confer an imprimatur of respectability on institutions otherwise resistant to change.

The 30 years or so since the second world war that have seen such a growth of academic surgery in the United Kingdom, but particularly in England, have been mainly if not exclusively devoted to research. The outcome of this has in many ways been 